\title{
Short Communication: The emergence and rise of indigenous thermophilic bacteria exploration from hot springs in Indonesia
}

\author{
KENNY LISCHER $^{1,2, \bullet}$, ANANDA BAGUS RICHKY DIGDAYA PUTRA ${ }^{1}$, BRIAN WIRAWAN GUSLIANTO ${ }^{1}$, \\ FORBES AVILLA ${ }^{1}$, SARAH GRACE SITORUS ${ }^{1}$, YUDHI NUGRAHA ${ }^{3}$, SARMOKO $^{4}$ \\ ${ }^{1}$ Bioprocess Engineering, Department of Chemical Engineering, Faculty of Engineering, Universitas Indonesia. Jl. Lingkar Akademik, Depok 16424, \\ West Java, Indonesia. Tel.: +62-21-7863516, "email: lischer.kenny@ui.ac.id \\ ${ }^{2}$ Research Center of Biomedical Engineering, Universitas Indonesia. Jl. Lingkar Akademik, Depok 16424, West Java, Indonesia \\ ${ }^{3}$ Faculty of Medicine, Universitas Pembangunan Nasional Veteran. Jl. Pangkalan Jati, Jakarta Selatan 12450, Jakarta, Indonesia \\ ${ }^{4}$ Department of Pharmacy, Universitas Jenderal Soedirman. Jl Dr. Soeparno, Purwokerto Utara, Banyumas 53122, Central Java, Indonesia
}

Manuscript received: 27 September 2020. Revision accepted: 27 October 2020.

\begin{abstract}
Lischer K, Putra ABRD, Guslianto BW, Avilla F, Sitorus SG, Nugraha Y, Sarmoko. 2020. Short Communication: The emergence and rise of indigenous thermophilic bacteria exploration from hot springs in Indonesia. Biodiversitas 21: 5474-5481. Indonesia is an archipelagic country located in the pacific ring of fire, and is estimated to cause numerous hot springs spread across the country. In addition, small living microbes have been explored in these locations since 1985. These microbes possess the ability to survive in areas with high temperature (more than $40^{\circ} \mathrm{C}-90^{\circ} \mathrm{C}$ ), and are therefore termed thermophiles. Hence, massive explorations have been conducted on Java island and other unexplored areas at Sumatra to Papua in New Guinea islands. Moreover, a total of 71 hot springs characterized by the presence of thermophilic bacteria have been explored in Indonesia. These investigations ensue with various approaches, including through conventional and microbiological, 16S rRNA, as well as whole-genome sequencing methods. In addition to species exploration, the application of thermophiles has become a topic of interest from 1999, especially based on thermostable enzymes with the capacity to maintain activity at high-temperature conditions. These include amylase, protease, lipase, xylanase, esterase, and cellulase as the most common isolated form, which indicates the existence of significant extractable potentials. Hence, there is a need for further research in terms of both exploration and application purposes.
\end{abstract}

Keywords: Hot spring, Indonesia, thermophilic bacteria, thermostable enzyme

\section{INTRODUCTION}

Thermophiles were first discovered in 1953 (Marsh and Larsen 1953), and attracted research interest after the isolation of Taq polymerase from Thermus aquaticus (Chien et al. 1976). This has been followed by the further exploration of microbes from hot springs, thus leading to scientific changes globally (Hugenholtz et al. 1998; Mori et al. 2003; Papke et al. 2003). In addition, numerous related discoveries, including the respective bacteria applications in industry have played a significant role in society. This action results from the potency to maintain activity in extreme environments, including at high temperatures and extreme pH (Chien et al. 1976; Skirnisdottir et al. 2000; Ferrer et al. 2007; Cox et al. 2011; Everroad et al. 2012). In addition, the various enzymes generated are considered to be thermostable, and also capable of contributing numerous benefits to the industry (Zamost et al. 1991).

Moreover, studies on geothermal ecosystems have added collections of microbial diversity and informative discoveries. The exploration methods have become more advanced, although previous approaches involved the use of culture and morphology (Marsh and Larsen 1953; Ward et al. 1998). This investigation is expected to remarkably uncover the diversity of thermophilic bacteria worldwide.
Therefore, advances in PCR and sequencing techniques have caused a shift in single cell-based analysis to the DNA level. The relatively common evaluation method adopted for species involves comparing the 16S rRNA of explored bacteria with GenBank library (Ward et al. 1998). However, the decline in genome sequencing cost facilitates the attraction of more detailed insight into thermophilic bacteria exploration, in terms of biodiversity, ecological significance, and application (Aliyu et al. 2016).

Indonesia is one of the countries in the world known to be traversed by the ring of fire, as well as numerous active volcanoes. In addition, a total of 70 volcanoes are spread from the island of Sumatra, Java, Bali, Sulawesi, Kalimantan, Maluku, and Papua (Manalu 1988), resulting in about 256 hot springs identified across the country (Darma et al. 2010). Despite the wide distribution, minimal attention has been attributed to microbial exploration and analysis at these sites. This paper, therefore, collectively compiles the studies of thermophile investigations, especially for thermophilic bacteria, and the outcomes from the first publications in Indonesia. Furthermore, these activities are conducted to provide an insight into the acknowledgment to date, and also to identify challenges for future research. 


\section{MATERIALS AND METHODS}

\section{Data acquisition}

The keyword "Indonesia thermophilic bacteria" was used to identify related original research papers and proceeding in scopus, pubmed, and google scholar, assumed to have relevant publications both at the international and national levels. The investigated journals were dated from 1991 to August 2020, and data on hot spring location, type of study, bacterial species, and application were obtained to generate a database. This information was required to produce graphs and diagrams of publication progress, type of study, and application (translational research), generated using the Prism Graphpad software.

\section{Generation of microbiologically explored hot springs map}

Google Map application was used to generate microbiologically explored hot springs with various color types, based on location and year. This was an approach to indicate the first exploration attempts at the desired site.

\section{RESULTS AND DISCUSSION}

\section{Progress of thermophilic bacteria exploration in Indonesia}

The keywords "Indonesia thermophilic bacteria" were used to identify related studies in Scopus, Pubmed, and Google Scholar. This was performed to acknowledge the progress of thermophilic bacteria exploration. Figure 1 shows the results extracted from 1991, and minimal research is available prior to 2010, where publications from Indonesia progressively emerged to 2020. This indicates the greater attractiveness of research trends in the aspect of thermophilic bacteria. Figure 1 shows an accumulation of 170 publications, and the improvements were possibly attributed to the availability and accessibility of experimental methods and materials, as well as support in form of research grant from the government (Wiryawan 2014).

\section{Hot spring locations of isolated thermophilic bacteria}

The next question is associated with how trends of hot spring locations subjected to microbiological life are explored. The Ministry of Energy and Mineral Resources, Republic of Indonesia has identified nearly 256 in-depth geophysical researches where geothermal gradients and tectonic elements were used throughout Indonesia (Darma et al. 2010). However, Figure 2 showed only 71 to have been explored microbiologically. These were spread across the islands of Java, Bali, Sumatra, Kalimantan, Sulawesi, and Papua, and a majority were easily accessible. Consequently, these spots were adopted as tourism spots, where people frequently engage in baths, based on the belief as a cure to skin diseases.

Figure 2 shows the initial microbiologically exploration of hot springs across the country. In addition, the dark and light blue colors were dominant around Java and Bali, indicating these areas as centric (around 1991-2010). The most interesting aspect of this graph is the spread in other islands outside Java and Bali island, initiated from 2004 as shown in Figure 2. Also, there is a significant increase in the number of new explorations on island of Sumatra, Kalimantan, Sulawesi, and Papua compared to Java and Bali. The efforts to identify thermophilic bacteria at Tompaso hot springs, Sulawesi island was initiated in 2004 (Yuli et al. 2004). This is followed by other initial reports at Sumatra in 2007, Papua in 2015, and Kalimantan in 2017 (Helianti 2007; Patasik et al. 2015; Taufik et al. 2017). Based on the first discovery in previously mentioned islands, numerous reports were conducted to enrich biodiversity data across Indonesia. These results collectively provide important insights into identification efforts in a wider region.

\section{Thermophilic bacteria analysis}

The next question entails identifying the methods commonly used to explore thermophilic bacteria in Indonesia. In addition, related information has also been made available during the past 30 years, and at least three methods adopted in the identification process., Moreover, 16S rRNA analysis was the most commonly used at 59\%, followed by the conventional $(38 \%)$ and whole-genome sequencing (2\%). The conventional method was determined to be the oldest, and is known to involve microbe culture and morphological identification (Marsh and Larsen 1953; Huber et al. 1991; Ward et al. 1998).

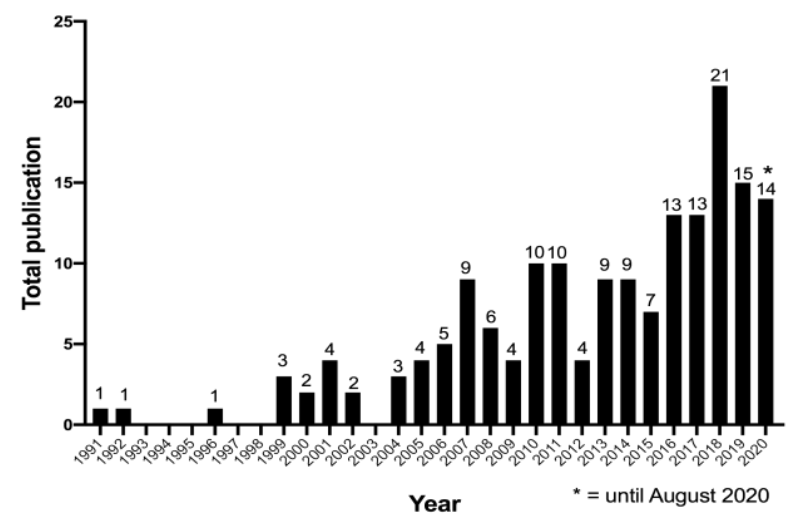

Figure 1. Progress of thermophilic bacteria publication in Indonesia. The list of publication can be viewed at this link (https://docs.google.com/spreadsheets/d/1tXhD-

dkAe3RYk_Al98guaYF7nstbZfYF1CLg7_X2QMI/edit?usp=shar ing) 


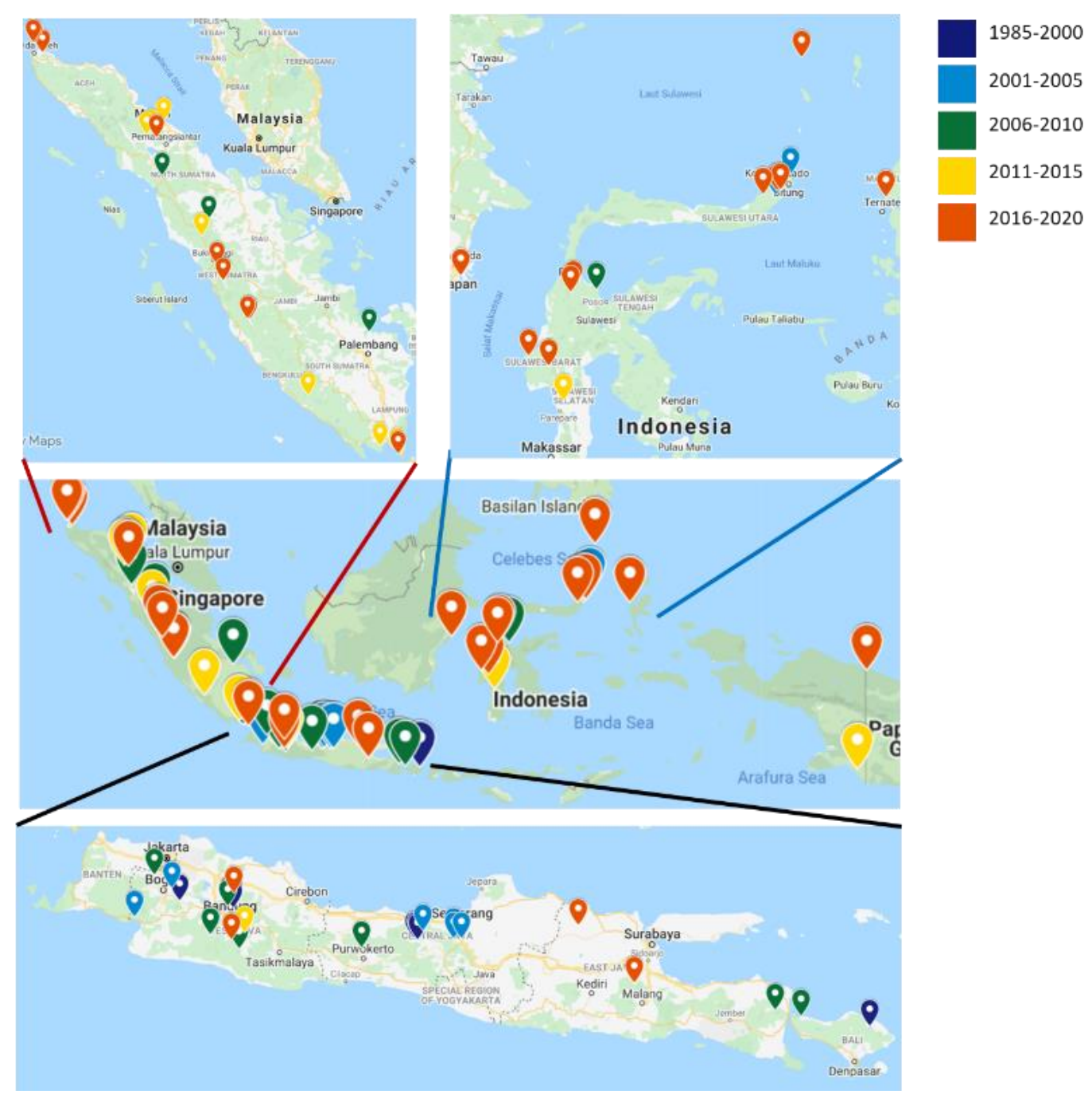

Figure 2. Distribution of microbiologically explored hot spring in Indonesia. These colors show the first attempt made to isolate microbes. The map is accessible through the link (https://www.google.com/maps/d/edit?mid=1-Kn7k1BAKfLVNbS_7_-BCdWEbt_f5xA\&usp=sharing).

This approach is essential in the characterization of thermophile isolates and the respective potentials, although only a small number were discovered. Furthermore, the preserved regions allow for simple PCR sample identification and, the sequence in most cases provides reliable information on the families, genus, or species. This analysis, therefore, shows information from the DNA level, with potential relevance on a broader scale (Huber et al. 1996; Ward et al. 1998). The whole-genome sequencing also generates data at the DNA level, but is least patronized due to the high analysis cost. However, 16S rRNA remains the most powerful tool applied in the discovery of microbes from hot spring in Indonesia.

\section{Explored application}

Numerous labs are commonly known to explore microbes in hot springs and also to evaluate the commercial applications. Figure 4 shows the various uses previously explored, where most focused on the enzyme related functions $(93 \%)$ than otherwise. This indicates the existence of a relationship between the bioprospecting trend in Indonesia and thermostable enzyme known to potentially sustain the individual activity at extreme conditions, including high temperature and $\mathrm{pH}$ (Chien et al. 1976; Skirnisdottir et al. 2000; Ferrer et al. 2007; Cox et al. 2011; Everroad et al. 2012). The top 4 explored enzymes include amylase $(17 \%)$, protease $(12 \%)$, lipase $(9 \%)$, and xylanase (8\%). Meanwhile, non-enzyme applications mostly involve the use of thermophilic bacteria in biosurfactant or biohydrogen production (Geraldi et al. 2019; Gazali et al. 2020).

\section{Discussion}

Hot springs in Indonesia have been examined based on three different objectives, including (1) novel species identification, (2) screening and characterization of different thermostable enzymes, and also (3) the diverse bio-resource applications. Figure 1 shows the explorations in 1991, which marked the initial research interest in microbe identification. In addition, approximately 8 
different species were recognized from the 9 selected hot springs, including Toya Bungkah, Sikidang, Candradimuka, Sileri, Domas, Badak, Djarian, Ciater, and Gunung Gede, respectively (Huber et al. 1991). Therefore, culture and morphological approaches were adopted at the time. Moreover, DNA polymerase production is known to shift the analytical methods from conventional based to the DNA level, by evaluating the bacteria $16 \mathrm{~S}$ rRNA through PCR (Ward et al. 1998). This approach was first performed by Huber et al. in 1996), before the whole-genome sequencing method by Cho et al. in 2000 .

The conventional method is known to be the oldest, and also has some limitations, resulting from the inadequate number of culturable microbes in the desired environment (Chaudhary et al. 2019). The current papers with reports on this technique were mainly based on samples sourced from Mount Pancar, West Java, and consequently used for hydrogen production, amylolytic bacteria isolated from Jailolo Bay, North Maluku, and amylase from Pulu hot spring, Sulawesi (Arfah et al. 2020; Gazali et al. 2020; Satrimafitrah et al. 2020). These indicate the reasons for a high percentage $(38 \%)$ application as an exploration method. In addition, some of the issues reported during the use of conventional microbiological methods include limitations in identification. Ijen, Solok, Sulili, Bora, and Jailolo are hot springs with different characteristics, and located far from one another on different islands. However, all of these surprisingly demonstrate similar isolates from genus Bacillus (Kusumadjaja et al. 2010; Harnentis et al. 2013; Hafsan et al. 2017; Ifandi and Alwi 2018; Arfah et al. 2020). Therefore, the documentation process is expected to be moved from the genus to species level, for the provision of better details.

Moreover, 16S rRNA analysis is one of the most commonly used methods in Indonesia (Huber et al. 1996; Ward et al. 1998). The preserved regions allow for simple PCR sample identification and, the respective sequence provides reliable information on the families, genus, or species. The bacteria data is revealed from the DNA level, which provides broader details (Huber et al. 1996; Ward et al. 1998). Consequently, the explored members of family Bacillaceae contain both Bacillus and another genus, including Anoxybacillus and Geobacillus, Alicyclobacilus, and Aneurinibacillus (Aminin et al. 2008; Rachma et al. 2009; Mantiri et al. 2019; Ginting et al. 2020; Mar et al. 2020). In addition, other families recognized include Paenibacillaceae explored from Prataan (Paenibacillus sp.), Cisolok (Paenibacillus cisolokensis), and Tutung (Brevibacillus borstelensis and Paenobacillus sp..) (Chrisnasari et al. 2016; Yokota et al. 2016; Arzita et al. 2017). Moreover, there were other microbes different from the order Bacillales, including the family Thermoanaerobacterales (Thermoanaerobacter yonseiensis) from Sileri, family Psedonocardiaceae (Gandjariella thermophila) from Cisolok, phylum thermotogae (Fervidobacterium islandicum), and phylum Deinococcus-thermus (Thermus aquaticus) from Kawah Hujan respectively (Kim et al. 2001; Nam et al. 2002; Febriani et al. 2011; Ningsih et al. 2019).
Meanwhile, another method estimated to use the DNA level includes the whole-genome sequencing, recognized for over 25 years, when reports about the first complete bacterial genome sequenced were published (Fleischmann et al. 1995; Fraser et al. 1995). This technology has the capacity to thoroughly study and identify hundreds or thousands of genomes (Land et al. 2015), and also contributes to a deeper understanding of genetic relationships compare to $16 \mathrm{~S}$ rRNA gene. In addition, this approach has become more interesting due to a drastic decline in costs, thus encouraging the application feasibility in numerous laboratories (Shendure and Ji 2008). Despite the reduced cost, there have also been reports on the relatively lower popularity (figure 3). This is possibly attributed to the limited availability of whole-genome sequencing machines in Indonesia. However, there are numerous benefits, including the ability to identify previously unexplored thermophilic bacteria from Sileri hot spring, including the Anoxybacillus kamchatkensis, Caldanaerobacter yonseiensis, and Fervidobacterium islandicum (Lee et al. 2012; Lee et al. 2013; Lee et al. 2015). Table 1 shows a summary of the discussions about the correlation of exploration methods and the evaluated bacteria.

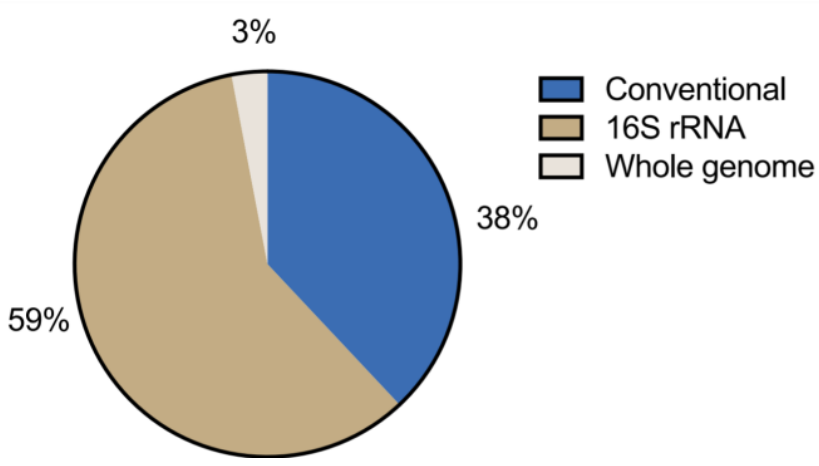

Figure 3. Type of exploration methods

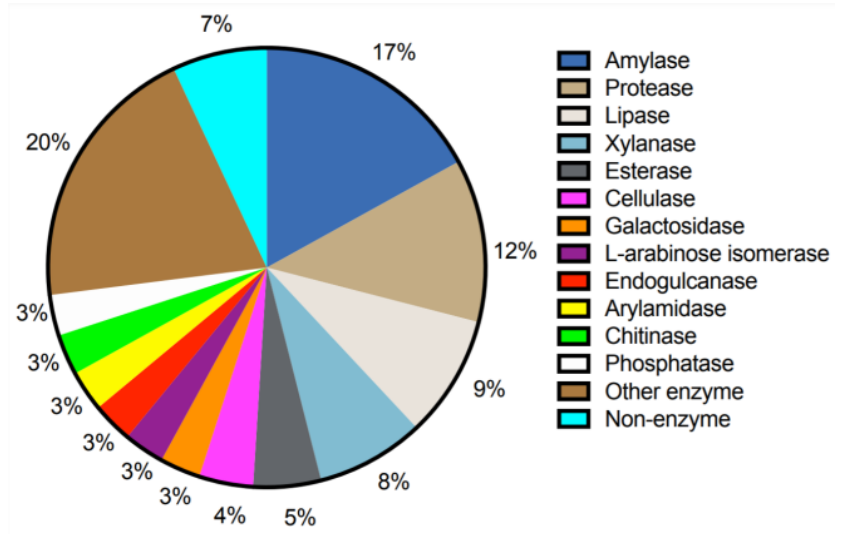

Figure 4. Application of explored thermophilic bacteria in Indonesia 
Table 1. Summary of exploration methods and type of microbes

\begin{tabular}{|c|c|c|c|c|c|c|}
\hline \multirow{2}{*}{ Method } & \multicolumn{5}{|c|}{ Explored microbes } & \multirow[t]{2}{*}{ References } \\
\hline & Phylum & Class & Order & Family & Genus & \\
\hline $\begin{array}{l}\text { Conventional } \\
\text { method }\end{array}$ & Firmicutes & Bacilli & Bacillales & Bacillaceae & Bacillus & $\begin{array}{l}\text { (Kusumadjaja et al. 2010; Harnentis et } \\
\text { al. 2013; Hafsan et al. 2017; Ifandi and } \\
\text { Alwi 2018; Arfah et al. 2020) }\end{array}$ \\
\hline \multirow[t]{6}{*}{ 16S rRNA } & Firmicutes & Bacilli & Bacillales & Bacillaceae & $\begin{array}{l}\text { Anoxybacillus, Geobacillus, } \\
\text { Alicyclobacilus, and } \\
\text { Aneurinibacillus }\end{array}$ & $\begin{array}{l}\text { (Aminin et al. 2008; Rachma et al. } \\
\text { 2009; Mantiri et al. 2019; Ginting et al. } \\
\text { 2020; Mar et al. 2020) }\end{array}$ \\
\hline & Firmicutes & Bacilli & Bacillales & Paenibacillaceae & Paenibacillus and Brevibacillus & $\begin{array}{l}\text { (Chrisnasari et al. 2016; Yokota et al. } \\
\text { 2016; Arzita et al. 2017) }\end{array}$ \\
\hline & Firmicutes & Clostridia & $\begin{array}{l}\text { Thermoanaerobac } \\
\text { terales }\end{array}$ & Thermoanaerobacteraceae & $\begin{array}{l}\text { Thermoanaerobacter } \\
\text { (Thermoanaerobacter yonseiensis) }\end{array}$ & (Kim et al. 2001) \\
\hline & Actinobacteria & Actinobacteria & Actinomycetales & Psedonocardiaceae & $\begin{array}{l}\text { Gandjariella } \\
\text { (Gandjariella thermophila) }\end{array}$ & (Ningsih et al. 2019) \\
\hline & Thermotogae & Thermotogae & Thermotogales & Thermotogaceae & $\begin{array}{l}\text { Fervidobacterium } \\
\text { (Fervidobacterium islandicum) }\end{array}$ & (Nam et al. 2012) \\
\hline & $\begin{array}{l}\text { Deinococcus- } \\
\text { thermus }\end{array}$ & Deinococci & Thermales & Thermaceae & $\begin{array}{l}\text { Thermus } \\
\text { (Thermus aquaticus) }\end{array}$ & (Febriani et al. 2011) \\
\hline \multirow[t]{3}{*}{$\begin{array}{l}\text { Whole-genome } \\
\text { sequencing }\end{array}$} & Firmicutes & Bacilli & Bacillales & Bacillaceae & $\begin{array}{l}\text { Anoxybacillus } \\
\text { (Anoxybacillus kamchatkensis) }\end{array}$ & (Lee et al. 2012) \\
\hline & Firmicutes & Clostridia & $\begin{array}{l}\text { Thermoanaerobac } \\
\text { terales }\end{array}$ & Thermoanaerobacteraceae & $\begin{array}{l}\text { Caldanaerobacter } \\
\text { (Caldanaerobacter yonseiensis) }\end{array}$ & (Lee et al. 2013) \\
\hline & Thermotogae & Thermotogae & Thermotogales & Thermotogaceae & $\begin{array}{l}\text { Fervidobacterium } \\
\text { (Fervidobacterium islandicum) }\end{array}$ & (Lee et al. 2015) \\
\hline
\end{tabular}


Figure 2 showed other progress recorded in this study, which was in terms of the region under investigation, and thermostable enzyme production. The identification procedure is performed across the country, as observed at the island of Java, Bali, Sumatra, Sulawesi, Kalimantan, and Papua, respectively (Huber et al. 1991; Yuli et al. 2004; Toharisman et al. 2005; Helianti 2007; Patasik et al. 2015; Taufik et al. 2017). In addition, samples from Java have currently been overstudied, as the exploration in Gedongsongo initially performed in 2007 was followed by multiple studies (Aminin et al. 2007; Aminin et al. 2008; Rachma et al. 2009; Kusdiyantini et al. 2017; Nuritasari et al. 2017; Rukmi et al. 2018). The major challenge observed is the highly similar results obtained with some, in the terms of bacteria type, as well as application (Rachma et al. 2009; Nuritasari et al. 2017; Rukmi et al. 2018). In addition, expansion of the identified species involves the use of Denaturing Gradient Gel Electrophoresis, followed by the 16S rRNA gene technique. This successfully showed previously unexplored genus, encompassing the Delftia, Ralstonia, and Thermus (Aminin et al. 2008). However, only $27 \%$ of the total hot springs have already been microbiologically evaluated, and many more exist across the country. These open an opportunity for further investigation of the possibilities for new microbial species. Furthermore, it is important to note preference for Java island analysis in terms of biodiversity, especially at Kalimantan, Sulawesi island, Papua, and other smaller islands. Moreover, developing an online database for thermophilic bacteria is necessary for compiling data from the explored environment.

Furthermore, thermostable enzymes were first produced directly from thermophilic bacteria in 1999 (Lee et al. 1999; Lestari et al. 1999). The lipase variant was extracted from Bacillus thermoleovorans ID-1 (Lee et al. 1999), while amylase was obtained from an unknown bacteria isolate in Dieng (Lestari et al. 1999). Specifically, the lipase gene had the capacity to clone into plasmids and was subsequently produced by Escherichia coli one year later (Cho et al. 2000). Despite the relatively low isolation of thermostable enzyme, there are minimal application variations.

The most common studies are related to the isolates' prospect during the degradation of carbohydrate derived compounds, including starch, lignocellulosic materials, saccharide, and chitin, recorded in over $50 \%$ of the total reports. In addition, amylase, in this case, is identified as the most frequently studied starch degrading variety (Zamost et al. 1991; Taufik et al. 2017; Satrimafitrah et al. 2020), while other lignocellulosic forms include cellulase and endoglucanase (Rachma et al. 2009; Suherman et al. 2020). Furthermore, exoglucanase with the capacity to decompose non-reducing and cellulose has not been explored. The combination of cellulose, endoglucanase, and exoglucanase enzymes possibly demonstrate enhanced degradation activity against lignocellulosic materials (Bronnenmeier et al. 1991). However, this research interest also acknowledged saccharide decomposing thermostable enzymes, including xylanase, galactosidase, L-arabinose isomerase, aldolase, and agarase (Fitriani and Saksono 2010; Saksono and Sukmarini 2010; Li et al. 2014; Suharti et al. 2015). Meanwhile, chitinase with the tendency to breakdown the glycosidic bonds in chitin is further investigated from isolated thermophilic bacteria in Indonesian hot springs (Chrisnasari et al. 2016).

In addition to the carbohydrate related degradation, enzymes for protein and lipid were also explored. These are possibly observed from numerous reports, as shown in the extraction of protease and lipase from isolated microbes (Lee et al. 1999; Febriani et al. 2011; Patasik et al. 2015; Nuritasari et al. 2017; Ginting et al. 2020). In addition, there was also minimal interest in the aspect of thermostable variants with DNA as the target. The explored application originated from Sikidang crater isolates (Brevibacillus sp.) and hot spring around Bandung (Geobacillus thermoleovorans) (Susanti et al. 2007; Witasari et al. 2010). Also, it is interesting to evaluate other uses including Thermo-Cas9 and Geo-Cas9, recognized as thermostable CRISPR/Cas9, with a tendency for DNA editing and sensoring (Harrington et al. 2017; Mougiakos et al. 2017).

Furthermore, there are numerous prospective applications of unexplored enzymes, and there is no evidence about possible antibacterial properties. The peptide termed Geobacillin is considered a candidate for isolation (Garg et al. 2012). Meanwhile, another interesting use of enzymes includes in plastic degradation activities. Previous reports showed the ability of Thermophilic Bacillus sp. BCBT21 and Brevibacillus borstelensis to degrade plastic and polyethylene, respectively (Hadad et al. 2005; Dang et al. 2018). The construction of bacterial consortium by adding thermophilic bacteria are also possibly acknowledged in the future (Sar et al. 2013). In addition, metagenomic approach can be taken to address other bioprospective enzymes of explored thermophilic bacteria.

The trend of thermostable application studies in Indonesia is mostly focused on activity test by measuring the degradation ability or rate. In addition, it is important to evaluate enzyme production optimization strategies both on a lab and large scale (industry). Surprisingly, there is small number of publications in this aspect (Wibowo et al. 2016; Indriati and Megahati 2017; Safitri et al. 2017). However, the enzymes observed in Indonesia are imported, although industrial scale research is required to generate more indigenous applications to be produced.

In conclusion, thermophilic bacteria have been discovered from hot springs in Indonesia since the year 1991. This was followed by a progressive increase in related topics. In addition, major studies explored the microbes present, while others emphasized thermophilic bacteria applications across the country. However, several researches are based on industrial uses, and there is no evidence of commercial-scale production. Therefore, it is necessary to address the gaps in the potential of successful translations. The long-term monitoring and conservation of the hot springs' natural ecosystem also demand attention in the aspect of commercial applications. 


\section{ACKNOWLEDGEMENTS}

The authors are grateful for the grant PUTI Q2 Nomor: NKB-1759/UN2.RST/HKP.05.00/2020 to support the research. In addition, KL created the study concept and engaged in the writing of this paper. SGS, FA, ABRDP, and BWG contributed to data collection and analysis. YN was involved in application and editing, while $S$ contributed in proofreading and substantive editing.

\section{REFERENCES}

Aliyu H, Lebre P, Blom J, Cowan D, De Maayer P. 2016. Phylogenomic re-assessment of the thermophilic genus Geobacillus. Syst Appl Microbiol 39 (8): 527-533.

Aminin ALN, Madayanti F, Aditiawati P. 2007. 16S Ribosomal RNAbased analysis of thermophilic bacteria in Gedongsongo Hot Spring. Microbiol Indones 1 (1): 9-9.

Aminin ALN, Warganegara FM, Aditiawati P. 2008. Simple enrichment and independent cultures to expand bacterial community analysis from Gedongsongo hot spring. J Biosci Bioeng 106 (2): 211-214.

Arfah RA, Lestari YA, Dali S, Liestianty D. 2020. The isolation of thermophilic-amylolytic bacterium and activity test of harsh extract amylase enzyme from the hot spring at Jailolo Bay in North Maluku. J Phys Conf Ser 1569 (4): 042050. DOI: 10.1088/1742 6596/1569/4/042049.

Arzita S, Agustien A, Rilda Y. 2017. The diversity of the alkaline protease producers, thermophilic obligate Bacillus spp., from Sungai Tutung Hot Spring, Kerinci, Jambi, Indonesia. J Pure Appl Microbiol 11 (4): 1789-1797.

Bronnenmeier K, Rucknagel KP, Staudenbauer WL. 1991. Purification and properties of a novel type of exo-1,4-beta-glucanase (avicelase II) from the cellulolytic thermophile Clostridium stercorarium. Eur J Biochem 200: 379-385

Chaudhary DK, Khulan A, Kim J. 2019. Development of a novel cultivation technique for uncultured soil bacteria. Sci Rep 9: 1-11.

Chien A, Edgar DB, Trela JM. 1976. Deoxyribonucleic acid polymerase from the extreme thermophile Thermus aquaticus. J Bacteriol 127: 1550-1557.

Cho AR, Yoo SK, Kim EJ. 2000. Cloning, sequencing and expression in Escherichia coli of a thermophilic lipase from Bacillus thermoleovorans ID-1. FEMS Microbiol Lett 186: 235-238.

Chrisnasari R, Yasaputera S, Christianto P, Santoso VI, Pantjajani T. 2016. Production and characterization of chitinases from thermophilic bacteria isolated from Prataan Hot Spring, East Java. J Math Fundam Sci 48 (2): 149-163.

Cox A, Shock EL, Havig JR. 2011. The transition to microbial photosynthesis in hot spring ecosystems. Chem Geol 280: 344-351.

Dang TCH, Nguyen DT, Thai H, et al. 2018. Plastic degradation by thermophilic Bacillus sp. BCBT21 isolated from composting agricultural residuals in Vietnam. Adv Nat Sci Nanosci Nanotechnol 9: $14-15$.

Darma S, Harsoprayitno S, Setiawan B, et al. 2010. Geothermal energy update: geothermal energy development and utilization in Indonesia. Proceedings World Geothermal Congress 2010, Bali, 25-29 April 2010. [Indonesia]

Everroad RC, Otaki H, Matsuura K, Haruta S. 2012. Diversification of bacterial community composition along a temperature gradient at a thermal spring. Microbes Environ 27: 374-381.

Febriani F, Madayanti RH, Akhmaloka. 2011. Production of thermostable alkaline lipase from Kawah Hujan Kamojang hot spring isolate. Proceedings of the Third International Conference on Mathematics and Natural Sciences. Institut Teknologi Bandung, Bandung, 23-25 November 2010. [Indonesian]

Ferrer M, Golyshina O, Beloqui A, Golyshin PN. 2007. Mining enzymes from extreme environments. Curr Opin Microbiol 10 (3): 207-214.

Fitriani D, Saksono B. 2010. Cloning of araA gene encoding 1-arabinose isomerase from marine Geobacillus stearothermophilus isolated from Tanjung Api, Poso, Indonesia. Hayati J Biosci 17 (2): 58-62.

Fleischmann RD, Adams MD, White O, Clayton RA, Kirkness EF, Kerlavage AR, Merrick JM. 1995. Whole-genome random sequencing and assembly of Haemophilus influenzae. Science 269 (5223): 496-512.

Fraser CM, Gocayne JD, White O, Adams MD, Clayton RA, Fleischmann RD, Fritchman JL. 1995. The minimal gene complement of Mycoplasma genitalium. Science 270 (5235): 397-404

Garg N, Tang W, Goto Y, Nair SK, Van Der Donk WA. 2012. Lantibiotics from Geobacillus thermodenitrificans. Proc Natl Acad Sci USA 109 (14): 5241-5246.

Gazali FM, Praharyawan S, Susilaningsih D. 2020. Dark fermentative hydrogen production from cheese whey using hydrogen-producing bacteria isolated from Mount Pancar hot spring, West Java. Proceeding of The International Symposium of Innovative BioProduction Indonesia on Biotechnology and Bioengineering 2019. Tangerang, Indonesia, 23-24 October 2019. [Indonesian]

Hariyanto S, Agustiana BND, Nastiti A, Alfiyanita RN, Gumilar I, Virginia TT, Kinayoh LR. 2019. Bioprospecting of cellulolytic and biosurfactant producing bacteria for organic waste treatment. Pollut Res 38: 114-117.

Ginting EL, Kemer K, Wullur S, Uria AR. 2020. Identification of proteolytic thermophiles from Moinit Coastal hot-spring, North Sulawesi, Indonesia. Geomicrobiol J 37 (1): 50-58.

Hadad D, Geresh S, Sivan A. 2005. Biodegradation of polyethylene by the thermophilic bacterium Brevibacillus borstelensis. J Appl Microbiol 98 (5): 1093-1100.

Hafsan H, Irwan II, Agustina L, Natsir A, Ahmad A. 2017. Isolation and Characterization of Phytase-Producing thermophilic Bacteria from Sulili Hot Springs in South Sulawesi. Sci Res J 5 (9): 16-19.

Harnentis YM, Rizal Y, Mahata ME. 2013. Isolation, characterization, and production of mannanase from thermophilic bacteria to increase the feed quality. Pak J Nutr 12 (4): 360-364

Harrington LB, Paez-Espino D, Staahl BT, Chen JS, Ma E, Kyrpides NC, Doudna JA. 2017. A thermostable Cas9 with increased lifetime in human plasma. Nat Commun 8 (1): 1-8.

Helianti IS. 2007. Direct cloning of a xylanase gene from Pawan-Riau hot spring. HAYATI J Biosci 14 (2): 54-58

Huber G, Huber R, Jones BE, Lauerer G, Neuner A, Segerer A, Degens E. T. 1991. Hyperthermophilic archaea and bacteria occurring within Indonesian hydrothermal areas. Syst Appl Microbiol 14 (4): 397-404.

Huber R, Rossnagel P, Woese CR, Rachel R, Langworthy TA, Stetter KO. 1996. Formation of ammonium from nitrate during chemolithoautotrophic growth of the extremely thermophilic bacterium Ammonifex degensii gen. nov. sp. nov. Syst Appl Microbiol 19 (1): 40-49.

Hugenholtz P, Pitulle C, Hershberger KL, Pace NR. 1998. Novel division level bacterial diversity in a Yellowstone hot spring. J Bacteriol 180 (2): 366-376.

Ifandi S, Alwi M. 2018. Isolation of thermophilic bacteria from Bora hot springs in Central Sulawesi. Biosaintifika J Biol Biol Educ 10: 291297.

Indriati G, Megahati R. 2017. Optimization medium of amylase production by Bacillus licheniformis strain MGI originated from Pariangan sot spring, West Sumatera, Indonesia. Intl J Adv Res 5 (11): 660-664.

Kim BC, Grote R, Lee DW, Antranikian G, Pyun YR. 2001. Thermoanaerobacter yonseiensis sp. nov., a novel extremely thermophilic, xylose-utilizing bacterium that grows at up to $85^{\circ} \mathrm{C}$. Int J Syst Evol Microbiol 51 (4): 1539-1548.

Kusdiyantini E, Darmawan AE, Wulandari D, Kusuma AB, Budiharjo A. 2017. Molecular and biochemical characterization of pink-pigmented thermophile bacteria (GDG IX) from Gedongsongo hot-spring in Bandungan-Semarang. Adv Sci Lett 23 (7): 6421-6423.

Kusumadjaja AP, Budiati T, Puspaningsih NNT, Sajidan S. 2010. Screening of thermophilic microorganism from Ijen crater Banyuwangi as phytase enzym producer. Indones J Chem 9 (3): 470473.

Land M, Hauser L, Jun S-R, Nookaew I, Leuze MR, Ahn TH, Poudel S. 2015. Insights from 20 years of bacterial genome sequencing. Funct Integr Genomics 15 (2): 141-161.

Lee DW, Koh YS, Kim KJ, Kim BC, Choi HJ, Kim DS, Pyun YR. 1999. Isolation and characterization of a thermophilic lipase from Bacillus thermoleovorans ID-1. FEMS Microbiol Lett 179 (2): 393-400.

Lee SJ, Lee YJ, Park GS, Kim BC, Lee SJ, Shin JH, Lee DW. 2013. Draft genome sequence of an anaerobic and extremophilic bacterium Caldanaerobacter yonseiensis isolated from a geothermal hot stream. Genome Announc 1 (6): 13. 
Lee SJ, Lee YJ, Ryu N, Park S, Jeong H, Lee SJ, Lee HS. 2012. Draft Genome Sequence of the Thermophilic Bacterium Anoxybacillus kamchatkensis G10. J Bacteriol 194 (23): 6684-6685.

Lee YJ, Jeong H, Park GS, Kwak Y, Lee SJ, Lee SJ, Lee DW. 2015 Genome sequence of a native-feather degrading extremely thermophilic eubacterium, Fervidobacterium islandicum AW-1. Stand Genomic Sci 10 (1): 71.

Lestari P, Richana N, Damardjati DS, Murdiyatmo U. 1999. Karakterisasi alpha-amilase dari isolat bakteri termofilik TH12. The Seminar Pertemuan Ilmiah Tahunan Perhimpunan Mikrobiologi Indonesia, Bandar Lampung, Indonesia, 14-15 December 1998. [Indonesian]

Li J, Sha Y, Seswita ZD, Hu Q, He P. 2014. Purification and characterization of thermostable agarase from Bacillus sp. BI-3, a thermophilic bacterium isolated from hot spring. J Microbiol Biotechnol 24 (1): 19-25.

Manalu P. 1988. Geothermal development in Indonesia. Geothermics 17 (3): 415-420.

Mantiri FR, Rumende RRH, Sudewi S. 2019. Identification of $\alpha$-amylase gene by PCR and activity of thermostable $\alpha$-amylase from thermophilic Anoxybacillus thermarum isolated from Remboken hot spring in Minahasa, Indonesia. Proceeding of The 12th Congress of Indonesian Society for Biochemistry and Molecular Biology in Conjunction With The 2nd International Conference Collaboration Seminar of Chemistry and Industry and AnMicro Workshop. Universitas Airlangga, Indonesia, 11-12 October 2018. [Indonesian]

Mar WW, Rohman A, Muwafiqi NH, Laras GA, Agustina D, Puspaningsih NNT. 2020. Short communication: Preliminary phylogenetic analysis of bacteria producing laccase isolated from Gunung Pancar, Bogor, Indonesia. Biodiversitas 21 (5): 2113-2118.

Marsh CL, Larsen DH. 1953. Characterization of some thermophilic bacteria from the hot springs of Yellowstone National Park. J Bacteriol 65 (2): 193-197.

Mori K, Kim H, Kakegawa T, Hanada S. 2003. A novel lineage of sulfatereducing microorganisms: Thermodesulfobiaceae fam. nov., Thermodesulfobium narugense, gen. nov., a new thermophilic isolate from a hot spring. Extremophiles 7 (4): 283-290.

Mougiakos I, Mohanraju P, Bosma EF, Vrouwe V, Bou MF, Naduthodi MI, Van Der Oost J. 2017. Characterizing a thermostable Cas9 for bacterial genome editing and silencing. Nat Commun 8 (1): 1-11.

Nam GW, Lee DW, Lee HS, Lee NJ, Kim BC, Choe EA, Pyun YR. 2002. Native-feather degradation by Fervidobacterium islandicum AW-1, a newly isolated keratinase-producing thermophilic anaerobe. Arch Microbiol 178 (6): 538-547.

Ningsih F, Yokota A, Sakai Y, Nanatani K, Yabe S, Oetari A, Sjamsuridzal W. 2019. Gandjariella thermophila gen. nov., sp. nov., a new member of the family pseudonocardiaceae, isolated from forest soil in a geothermal area. Int J Syst Evol Microbiol 69 (10): 30803086.

Nuritasari D, Sarjono PR, Aminin ALN. 2017. Isolasi bakteri termofilik sumber air panas gedongsongo dengan media pengaya MB (Minimal Broth) dan TS (Taoge Sukrosa) serta identifikasi fenotip dan genotip. J Kim Sains Apl 20 (2): 84-91. [Indonesian]

Papke RT, Ramsing NB, Bateson MM, Ward DM. 2003. Geographical isolation in hot spring cyanobacteria. Environ Microbiol 5 (8): 650 659.

Patasik IF, Runtuboi DYP, Gunaidi T, Ngili Y. 2015. Identification and characterization of thermophilic Bacillus sp. with protease activity at the fragment of 16S rRNA gene of several hot springs in Merauke, Papua-Indonesia. Der Pharma Chem 7 (7): 1-10.

Rachma A, Sarjono PR, Aminin ALN. 2009. Isolasi bakteri termofilik sumber air panas Gedongsongo dengan media pengaya minimal YT (Yeast Tripton) serta identifikasi genotipik dan fenotipik. J Kimia Sains dan Aplikasi 12 (3): 66-71. [Indonesian]

Rukmi I, Suprihadi A, Lunggani AT, Raharjo B. 2018. Eksplorasi mikroorganisme termofil indigenous dari sumber air panas
Gedongsongo sebagai penghasil enzim termostabil. Berk Bioteknol 1 (1): 1-8. [Indonesian]

Safitri A, Muharni, Kusumawati HY. 2017. Condition optimization production xylanase thermostable by Bacillus licheniformis TS10 using substrate oil palm empty fruit bunches. Biovalentia Biol Res J 3 (1): 8-16.

Saksono B, Sukmarini L. 2010. Structural Analysis of xylanase from marine thermophilic Geobacillus stearothermophilus in Tanjung Api, Poso, Indonesia. Hayati J Biosci 17 (4): 189-195.

Sar P, Kazy SK, Paul D, Sarkar A. 2013. Metal bioremediation by thermophilic microorganisms. In: Tulasi S, Jennifer L, Yutaka K (eds) Thermophilic Microbes in Environmental and Industrial Biotechnology. Springer, Netherlands.

Satrimafitrah P, Razak AR, Hardi J, Puspitasari DJ, Yelenggete I. 2020. Thermostable amylase activity produced by thermophilic bacteria isolated from Pulu Hotspring, Central Sulawesi. Proceeding of National Seminar on Physics 2019. Palu, Indonesia, 28 September 2019. [Indonesian]

Shendure J, Ji H. 2008. Next-generation DNA sequencing. Nat Biotechnol 26 (10): 1135-1145

Skirnisdottir S, Hreggvidsson GO, Hjörleifsdottir S, Marteinsson VT, Petursdottir SK, Holst O, Kristjansson JK. 2000. Influence of sulfide and temperature on species composition and community structure of hot spring microbial. Appl Environ Microbiol 66 (7): 2835-2841.

Suharti, Meray NW, Nurbaiti S. 2015. Cloning and expression of a novel gene-encoded thermostable archaeal aldolase class II from natural Sample. Biosci Biotechnol Res Asia 12 (2): 1023-1029.

Suherman EA, Moeis MR, Restiawaty E. 2020. Cloning and in silico study of endoglucanase from a thermophilic bacterium isolated from a hydrothermal vent of West Kawio, Sangihe-Talaud waters, North Sulawesi, Indonesia. Indon J Biotechnol 24 (2): 105.

Susanti E, Nurbaiti S, Madayanti F. 2007. Cloning, homological analysis, and expression of DNA Pol I from Geobacillus thermoleovorans. Intl J Integr Biol 1 (3): 206

Taufik M, Astuti W, Erwin. 2017. Screening thermophilic bacteria of amylase from Dondang Hot Springs In Muara Jawa Sub District. Proceeding of Seminar Nasional Kimia 2017, Samarinda, Indonesia, 4 September 2017. [Indonesian]

Toharisman A, Suhartono MT, Spindler-Barth M, Hwang JK, Pyun YR. 2005. Purification and characterization of a thermostable chitinase from Bacillus licheniformis Mb-2. World J Microbiol Biotechnol 21 (5): 733-738.

Ward DM, Ferris MJ, Nold SC, Bateson MM. 1998. A natural view of microbial biodiversity within hot spring cyanobacterial mat communities. Microbiol Mol Biol Rev 62 (4): 1353-1370.

Wibowo SG, Helianti I, Suryani A, Wahyuntari B. 2016. Application of response surface method in optimization of medium composition for xylanase production by Bacillus halodurans CM1 in submerged fermentation. Microbiol Indon 10 (3): 112-117.

Wiryawan KG. 2014. The current status of science journals in Indonesia. Sci Ed 1 (2): 71-75.

Witasari LD, Prijambada ID, Widada J, Wibawa DAA. 2010. Cloning of thermostable DNA polymerase gene from a thermophilic Brevibacillus sp. isolated from Sikidang Crater, Dieng Plateau, Central Java. Indon J Biotechnol 15 (2): 72-78.

Yokota A, Ningsih F, Nurlaili DG, Sakai Y, Yabe S, Oetari A, Sjamsuridzal W. 2016. Paenibacillus cisolokensis sp. nov. isolated from litter of a geyser. Int J Syst Evol Microbiol 66 (8): 3088-3094.

Yuli PE, Suhartono MT, Rukayadi Y, Hwang JK, Pyun YR. 2004. Characteristics of thermostable chitinase enzymes from the Indonesian Bacillus sp.13.26. Enzyme Microb Technol 35 (3): 147153.

Zamost BL, Nielsen HK, Starnes RL. 1991. Thermostable enzymes for industrial applications. J Ind Microbiol 8 (2): 71-81. 